\title{
Job’s Suffering: A Hypostatic Cry
}

\author{
Catherine Moon \\ Boston College School of Theology and Ministry (Brighton, MA)
}

\begin{abstract}
In this essay I will examine Thomas Aquinas' and Gustavo Gutierrez's respective commentaries on the Book of Job. I will look into how they reconcile Job, the exemplar of unmerited suffering, back to God. First I will analyze what the two theologians understand the central question of Job to be, then I will look into how they frame this question, how they interpret the speeches and the whirlwind, and then finally what they propose the answer to the suffering of the innocent to be.
\end{abstract}

\section{Text}

\section{Introduction}

How is God not only just, but good in a teleological sense from the perspective of the innocent, who suffer? This question goes beyond the typical scope of theodicy in that it does not beg for a metaphysical framework by which God is proven to be ontologically incapable of creating evil, but proceeds from the existential. It asks how individuals, who have suffered evil, encounter God as just and good and providential when God has pre-ordained their suffering from eternity by choosing to create in the first place. "Why should those who suffer ever be born? Why should life be given to those whose spirits are bitter? Why is life given to those who long for death that doesn't come?...[God] has surrounded me with nothing but trouble." (Job 3:20-21, 23). This is the lament of Job, the faithful servant, who suffered grievously and unjustly under God's watchful eye. To understand the plight of Job in himself as well as the fundamental truth the Book of Job as a whole seeks to profess is to understand the plight of all the innocent who suffer as well as what that suffering signifies about Creation as a whole.

Therefore, Thomas Aquinas and Gustavo propose that the answer to the suffering of the innocent is embedded in and inextricable from their interpretations of how Job, the exemplar of unmerited suffering, is reconciled to God. Thomas Aquinas and Gustavo Gutierrez, however, ground and frame their interpretations of the Book of Job differently from one another and thereby understand the innocent who suffer to be reconciled to God differently. The central question of the Book of 
Job for Thomas Aquinas is: how does Job demonstrate God's providence? For Gustavo Gutierrez, the central question is: how do innocent sufferers encounter God in light of the fact that their suffering has been preordained? Thomas approaches his central question by interpreting the Book of Job as an account of the progression of human knowledge from sense perception to divine revelation. Job, in having a correct understanding of the eternal order prior to encountering God, has a kind of inborn revelation that prefigures the Word becoming flesh. It is, thus, important from Thomas' perspective for Job to not be fictional because otherwise, the whole significance and the reality of Christ's presence throughout history prior to the Incarnation begins to be lost. Job's historicity, however, is completely inconsequential for Gustavo Gutierrez. What is of more importance to him is the authenticity of the innocent suffering of Job's human author, because reconciliation for Gutierrez is grounded in there being identity in suffering and the place where that identity occurs is on the cross with Christ. Therefore, while Thomas' Christology is more imminent and substantive with respect to the Book of Job, Gutierrez's Christology is more accidental. What is substantive and imminent about Gutierrez's Christology is suffering itself, rather than the person of Job. In this essay, I will demonstrate how both Thomas Aquinas and Gustavo Gutierrez reconcile the innocent who suffer to God through the mystery and power of Christ. How they do this is exemplified by their interpretations of Job and what it is to fully know God. First, I will show how Aquinas reconciles Job to God through emulating Christ's divine nature as the Word united with God. Then I will show how Gutierrez reconciles Job to God through emulating Christ's human nature as the crucified forsaken son. Through Thomas' and Gutierrez's interpretations I will show that the innocent who suffer are mostly fully reconciled to God through emulating both Christ's divine and human nature where everyone is called to know God through the cross and through temporal beatitude.

\section{A Beatific Rest in God}

Using the term reconciliation to refer to Thomas' interpretation of the culmination of the Book of Job is both appropriate and a tad misleading, due to his understanding of Job's right reason as Christological. It is misleading in that despite all of the questions Job poses to God and the laments he cries out, for Thomas, "he [does not say] these things...in despair of God, but because [Job] bore a higher hope about Him." . Job does not need to be reconciled to God because Job has not sinned nor has Job lost faith in God. After all, Job is blameless and he remains

${ }^{1}$ Thomas Aquinas, Commentary on the Book of Job, 19.2., trans. Brian Mulladay, ed. Joseph Kenney, Dominican House of Studies, accessed April 8, 2018. http://dhspriory.org/thomas/ $\underline{\text { SSJob.htm\#121. }}$ 


\section{MOON: JOB'S SUFFERING}

blameless as a result of always acting in accordance with God's proper order. Job's hope is an indication of his complete faithfulness in God. It is how Job persevered and did not blaspheme God, despite being told consistently by his friends how his suffering must be a consequence of his sin. In what sense then does Job need to be reconciled to God and is it appropriate to say that Job has been reconciled to God? Part of the glory of Job is that he hoped, amidst every death and every boil, that the one true God provided so much more than temporal pleasures. He had faith that God's power and love were so much greater than that. In calling out to God and begging for God's presence, "truly [Job] was not praying to be freed from adversity, but he prayed to be led to high-mindedness, and so he then says, 'and place me near you.' For since God is the very essence of good, it is necessary that he who is placed close to God, be freed from evil."2

This brings us to the manner in which it is appropriate to say Job is reconciled to God: in the whirlwind. The whirlwind brings Job to his proper end according to the eternal order because Job finally knows God as God rather than simply having divine knowledge. This goes back to the earlier point about Job's revelation being inborn rather than acquired through an encounter. That is to say, "the expectation Job had for his consolation in the midst of bitter things, [was to] be placed near to God where he could not fear attacks." "3 Although Job had right reason and could act righteously, he still lacked proximity to God. He could not abide in the loving rest for which his soul thirsted. This is what the reconciliation of Job to the whirlwind represents to Thomas. It is not simply knowing that God is love and human affairs are governed by Providence, but encountering God's love in the world amidst the suffering.

It is this kind of reconciliation to God in time that answers the question of the innocent suffering because it brings an end to all suffering. It does this, Thomas explains because when "man is perfectly placed near to God in his mind in the state of ultimate happiness... he cannot suffer attacks...because no matter how much someone would want to attack me, [he says] if I were placed perfectly near to you, no one's attack will disturb me." ${ }^{4}$ Therefore, God does not allow the innocent to suffer because He offers them rest from suffering in time. This same rest God offers Job in the whirlwind. For Thomas this conclusion is prophetic and Christological because Job explicitly says, "For I know that my redeemer lives." ${ }^{5}$ Christ, as God incarnate, who suffered and died in order to reconcile humanity to God, by offering up himself as the eternal Lamb and sending forth his indwelling Spirit, is the means by which we can all temporally find comfort and rest in the eternal whirlwind. Job's ability to receive the whirlwind and find that comfort in God, not simply at the

\footnotetext{
${ }^{2}$ Commentary on the Book of Job, 17.1.

${ }^{3}$ Commentary on the Book of Job, 17.1.

${ }^{4}$ Commentary on the Book of Job, 17.1.

${ }^{5}$ Commentary on the Book of Job, 19.2.
} 


\section{MOON: JOB'S SUFFERING}

eschaton, but in time, both prefigures Christ and seems to imply that Christ's intercession is a-temporal and therefore, fully present across time.

This need for a Christological intercession is further implied by the culmination of the text because Job's friends must not only be reconciled to the God of whom they spoke so wrongly, but they must also be reconciled to Job. For to convict Job when he is innocent is also to convict God. It is to convict God of not being love and not operating from love. God is convicted in the friends' belief in temporal retribution because it is not possible for a temporal order directed toward retribution to be grounded in love and to truly operate through free will.

According to Thomas Aquinas, God inclines the creature towards its final end according to the creature's proper mode, i.e. its nature, because God's providence is directed from love. The mode by which human beings are properly directed is by their free will. Temporal retribution directs the human will towards passable goods rather than to the impassable God. Under temporal retribution love becomes obscured because all action becomes self-interested, as does free will. It is unclear if people are choosing to do something out of a real synthesis of their will and intellect or if they are strictly acting in accordance with appetite.

Job's friends must be reconciled to him because they deepened his suffering by refusing to empathize with him. They neglected and consequently failed at their duty as friends "for the duty of the counselor is to say something by which the suffering will be mitigated." In failing at their duty as friends they not only convicted Job when he was innocent, but they also convicted God. Now it is only through the love and free will of Job himself that his friends can be reconciled to God. This is because "those who lack faith ought to be reconciled to God through the faithful, [thus, God] says, 'Go to my servant Job,' so that you may be reconciled to me by his mediation."7 In this way, Job becomes the necessary lamb, who mediates between God and those who have failed in their righteousness, still affording them the opportunity to find rest and happiness in a place untouched by suffering. As one can see, according to Thomas Aquinas, the overarching lesson and primary answer set forth by the Book of Job is that "Man's essential reward, which is his beatitude, consists in the perfect union of the soul with God, inasmuch as it enjoys God perfectly as seen and loved perfectly." 8

\footnotetext{
${ }^{6}$ Commentary on the Book of Job, 16.1.

${ }^{7}$ Commentary on the Book of Job, Epilogue.

${ }^{8}$ ST IIIa, q. 96, a. 1.
} 


\section{The Wager: An End to Sorry Comforters and a Start to Love \& Mystery}

The reconciliation present within the Book of Job for Gustavo Gutierrez begins with the very impetus of Job's suffering and what Gutierrez calls Satan's wager. Job's entire episode begins because "the enemy continues to think that Job's piety and justice are not disinterested; that the reason he behaves as he does is the material rewards he has received; that his actions are not truly free and disinterested." "The Book of Job, as a result, only ends in God's triumph if true faith is properly shown to be disinterested. Part of what the enemy reveals is "that a utilitarian religion lacks depth and authenticity; in addition, it has something satanic about it."10 In this way, Gutierrez's interpretation of Job's friends who speak wrongly of God and think God to operate according to retribution is far more condemning than Thomas' interpretation.

According to Gutierrez, to speak wrongly of God in this way is to speak in accord with Satan. This point is so important to Gutierrez because from his perspective "the expectation of rewards that is at the heart of the doctrine of retribution vitiates the entire relationship and plays the demonic role of obstacle on the way to God. In self-seeking religion there is no true encounter with God but rather the construction of an idol." "11 By Gutierrez's standard Job's friends are guilty of standing with Satan and worshipping idols. That is how far astray they have been led by their reason that is not driven by faith, but self-interest. Despite believing themselves to be holy and knowledgeable men, they are actually ignorant sinners because their faith did not begin with contemplation and an individual encounter with God. It instead began with what Gutierrez would term theology. Job's friends spoke of God and "developed" the doctrine of retribution before ever having really contemplated or encountered God.

Therefore, in so far as Job is representative of the Latin American poor for Gutierrez, Job by the end of the book has demonstrated to the Latin American poor how to speak to God amidst their innocent suffering. Job is an exemplar because "adversity does not cause him to lose innocence. The author wants to make it clear that Job's perseverance in his religious outlook is a further expression of his disinterestedness." 12 Job's disinterested faith is a sign of his proper contemplation, that he has not been so bold as to speak of God without the experiential knowledge to back it up. This is a state of innocence. Gutierrez sees a direct connection between entering into God's presence and recognizing that God does not operate according

${ }^{9}$ Gustavo Gutierrez, On Job: God-talk and the Suffering of the Innocent (Maryknoll, NY: Orbis Books, 1987), 6.

${ }^{10}$ Gutierrez, 5.

11 Gutierrez, 5.

12 Gutierrez, 6. 


\section{MOON: JOB'S SUFFERING}

to retribution. In this way, Gutierrez switches the order of knowledge and revelation from what we saw in Thomas. He does this when he says:

The truth that [Job] has grasped and that has lifted him to the level of contemplation is that justice alone does not have the final say about how we are to speak of God. Only when we have come to the realize that God's love is freely bestowed do we enter fully and definitively into the presence of faith...God's love, like all true love, operates in a world not of cause and effect but of freedom and gratuitousness. ${ }^{13}$

Where for Thomas revelation is what enables Job to righteously know that Providence is an outflow of gratuitous love. For Gutierrez knowing that God is a God of gratuitous love rather than one based in self-interest is the point of departure for revelation and being able to contemplate God. However, according to Gutierrez, this disinterested faith that opens one to the horizon of contemplation is Christological because "in the Book of Job, to be a believer means sharing human suffering, especially that of the most destitute, enduring spiritual struggle, and finally accepting the fact that God cannot be pigeonholed in human categories." 14 Gutierrez does not see Job as having spoken rightly of God because of some inborn revelation or faith. He instead thinks of Job as having thwarted the opportunity to speak wrongly of God, by choosing not to stay and wallow in his own pain, but to use his own suffering as a way to empathize and move into the suffering of others. Gutierrez believes the only way one can actually comfort the suffering is by fully embodying and experiencing that suffering alongside the sufferer. There is no room for sympathy in solidarity. It is insufficient. This is why Gutierrez is so harsh with regard to Job's friends, for they embody Christ's antithesis. They are concerned only with themselves and preserving their precious knowledge about the world and its ordering, so that they feel protected from hardship and not burdened with the work of mystery, which might dispel them of their earthly comforts and call them forth to the solidarity of suffering. ${ }^{15}$

The culmination of the Book of Job for Gustavo Gutierrez is mystery. Simply speaking, mystery, and one's proper contemplation of mystery, is what leads someone to choose to meet the suffering where they are: in their suffering. For Gutierrez the knowledge that comes with theology can settle people too easily into a worldview that either blames or ignores the suffering. Gutierrez answers that those who suffer unjustly enter into a loving encounter with God through the Pas-

\footnotetext{
${ }^{13}$ Gutierrez, 87.

${ }^{14}$ Gutierrez, 17.

${ }^{15}$ Gutierrez, 29.
} 
chal mystery. Gutierrez explains this by saying, "Only if we take seriously the suffering of the innocent and live the mystery of the cross amid that suffering... in the light of Easter, can we prevent our theology from being 'windy arguments."'16 Knowledge about God is useless, and not really knowledge at all, unless one encounters the constant mystery of God. It is clear that for Gutierrez the mystery of God is the suffering of Christ. That center of the world is where the author of Job went and where the Latin American poor and all other people must go in order to encounter God as love. For love, as we learned from Satan, is entirely disinterested. The height of disinterested love, as we learn from Job, is to willfully, and in an act of self-emptying, take on the suffering of others. Christ willfully took on the suffering of all. Therefore, the message of the Book of Job is to call everyone into the mystery, into the cross. For "the mystery is the one proclaimed by the dead and risen Son of God. It is the mystery that we come to know when his Spirit impels us to say 'Abba! Father!"17

\section{Conclusion}

In conclusion, Thomas Aquinas and Gustavo Gutierrez agree that the Book of Job answers the cries of the innocent who suffer through showing that the world is not ordered according to retribution and that Providence resides in gratuitous love that gifts freedom to all human beings. They also agree that the ultimate manifestation of this gratuitous love and the will of God to lead human beings to their final end is in Christ's eternal intercession and the sending forth of His comforting Spirit. They do differ with regard to how the suffering reconcile themselves to God. According to Thomas, it is very much through the indwelling of the Spirit that the suffering find safety from temporal hardship. Gutierrez focuses more on not taking away the suffering, but inhabiting it so deeply that the sufferer becomes one with Christ and by doing so, becomes one with all who suffer. I do not think these two interpretations of Job are mutually exclusive. On the contrary, it seems to me as though in combination these two reconciliations create human beings who both can participate in beatitude and be fully present in the suffering of this life, alongside those who suffer. These two understandings of Job mimic the hypostatic union where Christ was fully one with God and at the same time fully one with humanity. To fully be reconciled to God, we must experience suffering the way Christ experienced suffering and the way Job experienced suffering: in solidarity and beatitude.

\footnotetext{
${ }^{16}$ Gutierrez, 103.

${ }^{17}$ Gutierrez, 103.
} 


\section{MOON: JOB'S SUFFERING}

\section{Bibliography}

Aquinas, Thomas. Commentary on the Book of Job. Edited by Joseph Kenney. Translated by Brian Mulladay. Dominican House of Studies. Accessed May 11, 2017. http://dhspriory.org/thomas/SSJob.html.

Aquinas, Thomas, The Summa Theologiae of St Thomas Aquinas. Translated by the Fathers of the English Dominican Province. New Advent. Accessed May 11, 2017. http://www.newadvent.org/summa/1001.html.

Gutiérrez, Gustavo. On Job: God-talk and the Suffering of the Innocent. Maryknoll, NY: Orbis Books, 1987. 